\title{
Effects of abiotic factors on cell biomass and rosmarinic acid production in cell suspension cultures of Orthosiphon Stamineus benth
}

\author{
Laleh Bordbar ${ }^{1 *}$, Sreeramanan Subramaniam1, Nad-ali Babaeian Jelodar², Lai Keng Chan' \\ ${ }^{1}$ School of Biological Sciences, Universiti Sains Malaysia, 11800, Penang, Malaysia; ${ }^{2}$ Department of Plant Breeding, College of Agriculture, \\ Sari Agricultural Sciences and Natural Resources University, Sari, Mazandaran, Iran. P. O. Box 578
}

\section{A B S TR A C T}

\begin{abstract}
Orthosiphon stamineus Benth. is a medicinal plant belongs to Lamiaceae family. Due to the high variations in rosmarinic acid produced from the field-derived plants, cell suspension culture techniques was previously suggested and practiced as the alternative for cell biomass and rosmarinic acid (RA) production. In the present study, the effects of medium $\mathrm{pH}$, photoperiod, temperature and sucrose were evaluated on cell biomass and rosmarinic acid production using three different cell lines of $O$. stamineus. This study revealed that the slow and intermediate growing cell lines had similarities in terms of growth pattern. However, cells cultured in medium supplemented with lower sucrose concentration $(30 \mathrm{~g} / \mathrm{L})$ were more productive in terms of cell biomass and RA in the intermediate and fast growing cell lines however slow growing cells cultured in proliferation medium with $45 \mathrm{~g} / \mathrm{l}$ sucrose produced higher amount of RA. Medium pH in the range of 5.65-5.8 was optimal for both cell biomass and RA production. Photoperiod did not have a consistent effect on the three cell line's biomass production but the alternation of darkness and illumination led to high RA production in the slow growing cell line. This study proved that abiotic factors including medium $\mathrm{pH}$, photoperiod, temperature and carbohydrate source had impacts on cell biomass and rosmarinic acid production although in a diverse range among different growing cell lines.
\end{abstract}

Keywords: Cell suspension culture; Rosmarinic acid; Orthosiphon stamineus

\section{INTRODUCTION}

Orthosiphon stamineus Benth (Family: Lamiaceae), also known as Misai kucing (Malaysia), kumis kucing (Indonesia), and Java tea (Europe), is a native plant to South East Asia (Indubala and $\mathrm{Ng}, 2000)$. In Malaysia, O. stamineus has been widely used for treating kidney problems, fever, hypertension, gout, diabetes, hepatitis, epilepsy, gallstones, rheumatism, renal stones and jaundice (Ohashi et al., 2000; Mat-Salleh and Latiff, 2002; Chin et al., 2008).

Previous studies reported that $O$. stamineus contained caffeic acid, cirrchoric acid, diterpenes, orthosiphols, monoterpenes, triterpenes, saponins, hexoses, organic acids, rosmarinic acids, sinensetin, eupatorin, and 3'-hydroxyl-5,6,7,4'-tetramethoxyflavone (Jaganth and $\mathrm{Ng}$, 2000; Olah et al., 2003; Akowuah et al., 2005). It is a perennial herb, approximately $0.3-1 \mathrm{~m}$ in height. The stem is four angled with simple apposite leaves. Flowers are white or lilac with exceeding stamens coming out of collora tube (Wiart, 2002).

Rosmarinic acid (RA) was the main secondary metabolite isolated from the cell suspension cultures of O. stamineus (Sumaryono et al., 1991). RA has antifungal, antibacterial effects and is also used for predator protection in plants (Peterson, 1994; Pal Bais et al. 2002). In addition used as food preservative, antioxidant, antibacterial antiviral and anti-inflammatory (Cuvelier et al., 1996; Chen and Ho, 1997), RA also prevents anxiety or depression (Takeda et al., 2002).

O. stamineus is generally propagated vegetatively by cuttings, but rooting difficulties inhibits fulfilling the market demands (Lee and Chan, 2004). Biotechnological technique which is a good alternative has the privilege of screening in cells rather than intact plants (Akin-Idowu et al., 2009). In vitro propagation protocols for O. stamineus has been established 
(Lee and Chan, 2004; Lim et al., 2006). The optimization of medium for callus induction of $O$. stamineus was also established by Lee and Chan (2004). However, there are no studies so far classifying the differences among fast, intermediate and slow growing cell lines of $O$. stamineus.

The objectives of the present study were to evaluate the effects of medium $\mathrm{pH}$, photoperiod, temperature and sucrose concentrations on cell biomass and RA production of three different selected growing cell lines (fast, intermediate and slow) of this species.

\section{MATERIALS AND METHODS}

\section{Callus induction}

Two in vitro plant lines of $O$. stamineus, maintained in Plant Tissue and Cell Culture Laboratory, School of Biological Sciences, Universiti Sains Malaysia, Penang were used for the callus induction. The leaves were dissected $(0.5 \mathrm{~mm} \times 0.5 \mathrm{~mm})$ and weighed and inoculated on MS (Murashige and Skoog, 1962) medium supplemented with $1 \mathrm{mg} / \mathrm{L} \mathrm{NAA}$ and $1 \mathrm{mg} / \mathrm{L}$ 2,4-D (Lee and Chan, 2004). Ten (10) replicates were used in this study. Three (3) leaf explants were cultured in each vessel and they were maintained at temperature $25 \pm 2^{\circ} \mathrm{C}$ under continuous illumination using cold white fluorescent tubes at intensity of $32.5 \mu \mathrm{Em}^{-2} \mathrm{~s}^{-1}$ for six weeks. Induced callus from leaves were weighed and the subculture procedure was continued every three weeks for the subsequent study.

\section{Categorization and selection of callus lines}

From each line, total of $0.5 \mathrm{~g}$ callus was inoculated on MS medium supplemented with $1 \mathrm{mg} / \mathrm{L} \mathrm{NAA}$ and $1 \mathrm{mg} / \mathrm{L}$ 2,4-D. All the cultures were maintained at $25 \pm 2^{\circ} \mathrm{C}$ under continuous illumination at intensity of $32.5 \mu \mathrm{Em}^{-2} \mathrm{~s}^{1}$. The fresh callus weight was recorded after three weeks. This procedure was repeated nine times. Growth index was calculated for each subculture cycle using the following formula: Growth index (GI) = final weight - initial weight /initial weight

After nine subculture cycles, callus lines were categorized as fast (GI $>7)$, intermediate $(5 \leq \mathrm{GI} \geq 7)$ and slow growing $(\mathrm{GI}<5)$, on the basis of their growth index. To determine the harvesting day for each cell line, fresh callus mass of $0.75 \mathrm{~g}$ from one representative of each growing cell line (fast, intermediate and slow) was weighed and inoculated into $100 \mathrm{~mL}$ Erlenmeyer flasks containing $20 \mathrm{~mL}$ liquid cell proliferation medium (MS medium, supplemented with $1 \mathrm{mg} / \mathrm{L} \mathrm{2,4-D}$ and $1 \mathrm{mg} / \mathrm{L} \mathrm{NAA}$ ). Every three days, five random samples from each growing cell line (fast, intermediate and slow) were collected and the fresh cell biomass was determined after cells filtered through
Whatman filter papers (No.1) using Buncher funnel connected to a vacuum pump. Fresh cells were air-dried until the constant weight was achieved. The growth pattern of each cell line was determined based on the fresh and dried cell masses.

\section{Study of abiotic factors}

The influence of abiotic factors was studied on cell biomass and rosmarinic acid production of the three cell lines of O. stamineus. Cell proliferation medium (MS medium plus $1 \mathrm{mg} / \mathrm{L} \mathrm{NAA}$ and $1 \mathrm{mg} / \mathrm{L}$ 2,4-D) was experimented by using two sucrose concentrations $(30 \mathrm{~g} / \mathrm{L}$ and $45 \mathrm{~g} / \mathrm{L})$. Effect of pre autoclaved medium $\mathrm{pH}$ in different levels $(5,5.50,5.65,5.70,5.75,5.80,6$ and 6.50$)$ was observed. In this study medium was prepared and adjusted to different pH levels (EUTECH-510) before autoclaving. Photoperiod impact was studied on the three cell lines. In this study, each cell line was grown under different conditions: Continues illumination, total darkness (flasks were covered by aluminium foil), the first half growth cycle was illumination followed by darkness for the second half and the first half growth cycle was darkness followed by illumination for the second half. The cells were also incubated at different temperatures $\left(20,23,26\right.$ and $\left.29^{\circ} \mathrm{C}\right)$. In all experiments, each cell line was studied individually hence, tests carried out using completely randomized design (CRD) and the data were analysed using One-Way ANOVA. The significant differences of means were compared using Tukey test at $\mathrm{p} \leq 0.05$.

\section{Rosmarinic acid (RA) detection using ultra performance liquid chromatography (UPLC) system}

In order to detect rosmarinic acid, total of $0.5 \mathrm{~g}$ dried cells of each cell line (fast, intermediate and slow), derived from sucrose, medium $\mathrm{pH}$, photoperiod and temperature experiment was grinded into powder and soaked in $10 \mathrm{ml}$ methanol and put on a rotary shaker $(120 \mathrm{rpm})$ for 24 hours. It was then filtered by using filter paper No.1. After the methanol was evaporated, the remained extract was diluted with methanol HPLC grade using Millipore filter $(0.20 \mu \mathrm{m})$. The Quantitative estimation of RA was carried out using UPLC system (Waters UPLC ${ }^{\mathrm{TM}}$ ) equipped with C18 2.1×50 mm (1.7 M) with a flow rate of $0.25 \mathrm{ml} / \mathrm{min}$. The PDA detector wavelength was set to $210-400 \mathrm{~nm}$. For RA detection two mobile phases were used, mobile phase A consisted of $10 \%$ acetonitril, $1 \%$ acetic acid and $90 \%$ distilled water and mobile phase $\mathrm{B}$, consisted of $45 \%$ acetonitril and $55 \%$ distilled water (Lim et al., 2006). RA content was determined by comparing sample curves with the RA standard curve (Aldrich Chem. Co.). Rosmarinic acid standard was serial diluted (1000-3500 ppm) and it was injected before each sample run. Using rosmarinic acid standard curves in different concentrations provided us 
a formula to compute the quantity of rosmarinic acid found in the samples.

\section{RESULTS AND DISCUSSION}

\section{Callus induction}

Two callus lines (ZFIN and ZIIN) were induced and added to eight other previously provided callus lines $(\mathrm{MK}, \mathrm{SA}$, BF, ZI, ZZ, ZZNEW, II and ZF) for a more accurate selection study. In this procedure the excised leaf pieces enlarged and swollen when cultured on the callus induction medium after seven days. The callus formation first took place at the cutting edges of the leaf pieces. The callus cells gradually grew over the leaf pieces. The friable callus was established after nine subculture cycles. Callus lines were categorized into three main groups, on the basis of growth index, the fast, intermediate and slow growing lines. At the end of nine subculture cycles, callus lines were categorized. The induced callus line, ZIIN, was eliminated after $6^{\text {th }}$ subcultures due to abnormal growth. Four callus lines were categorized as fast growing lines, four lines as intermediate growing lines and only one was categorized as slow growing line (Table 1).

\section{Growth pattern of the three cell lines}

Growth pattern of the three selected cell lines (line MK for slow, line ZF for intermediate and line SA for fast growing) showed that there was a short lag phase (three days after inoculation) followed by a long logarithmic phase that took 12 days in the fast growing cell line and 15 days in the slow and intermediate growing cell lines. The fast growing cell line reached the stationary phase in 15 days and completed a growth cycle whereas the intermediate and slow growing cell lines reached the stationary phase in 18 days. Fast growing cell line had the longest stationary phase. This cell line produced more aggregated cells while the slow and intermediate growing lines produced more fine and separated cells. Comparing the dried and fresh cell biomass showed that cells contained mainly water. Growth pattern results indicated that regardless of differences among the three cell lines, the slow and intermediate growing cell lines of O. stamineus were more similar (Fig. 1).

Effect of sucrose, medium $\mathrm{pH}$, photoperiod and temperature on cell growth and rosmarinic acid production

Cells cultured in the cell proliferation medium (MS plus $1 \mathrm{mg} / \mathrm{L}$ 2,4-D and $1 \mathrm{mg} / \mathrm{L} \mathrm{NAA}$ ) supplemented with $30 \mathrm{~g} / \mathrm{L}$ sucrose produced significantly higher fresh cell biomass in the intermediate and fast growing cell lines. Fast growing line produced $3.36 \mathrm{~g}$ of cell mass when cultured in cell proliferation medium supplemented with $30 \mathrm{~g} / \mathrm{L}$ sucrose while in cell proliferation medium with $45 \mathrm{~g} / \mathrm{L}$ sucrose the cell biomass production was decreased by almost 50 percent $(1.31 \mathrm{~g})$. The same trend was observed in the intermediate growing cell line while the growth of the slow growing cell line was not affected by the amount of sucrose presented in the cell proliferation medium (Table 2).

With regards to rosmarinic acid (RA) production, only the slow growing cell line favoured RA production when cultured in cell proliferation medium supplemented with $45 \mathrm{~g} / \mathrm{L}$ sucrose. However, the intermediate cell line showed higher amount of RA when cell proliferation medium was

Table 1: Categorization of callus lines of Orthosiphon stamineus based on growth index

\begin{tabular}{lcc}
\hline $\begin{array}{l}\text { Slow growing } \\
\text { lines }(\mathrm{GI}<5)\end{array}$ & $\begin{array}{c}\text { Intermediate growing } \\
\text { lines }(\mathbf{5} \leq \mathrm{Gl} \leq \mathbf{7})\end{array}$ & $\begin{array}{c}\text { Fast growing } \\
\text { lines }(\mathrm{GI}>\mathbf{7})\end{array}$ \\
\hline $\mathrm{MK}(2.2)$ & $\mathrm{ZFIN} \mathrm{(6.0)}$ & $\mathrm{SA}(8.1)$ \\
& $\mathrm{ZF}(6.3)$ & $\mathrm{BF}(7.2)$ \\
& II $(6.1)$ & $\mathrm{ZI}(7.7)$ \\
& ZZNEW (5.4) & ZZ (7.1) \\
\hline
\end{tabular}

Table 2: Effect of sucrose supplemented in cell proliferation medium (MS + $1 \mathrm{mg} / \mathrm{L}$ NAA and $1 \mathrm{mg} / \mathrm{L} 2,4-\mathrm{D})$ on cell biomass production of $O$. stamineus cell lines

\begin{tabular}{lccc}
\hline Sucrose & \multicolumn{3}{c}{ Fresh biomass $(\mathbf{g}) \pm$ SE } \\
\cline { 2 - 4 } concentration $(\mathbf{g} / \mathbf{L})$ & Fast & Intermediate & Slow \\
\hline 30 & $3.36 \pm 0.18 \mathrm{a}$ & $2.51 \pm 0.23 \mathrm{a}$ & $1.40 \pm 0.03 \mathrm{a}$ \\
45 & $1.31 \pm 0.20 \mathrm{~b}$ & $1.44 \pm 0.06 \mathrm{~b}$ & $1.34 \pm 0.03 \mathrm{a}$ \\
\hline
\end{tabular}

The mean values of each column followed by the same alphabets were not significantly different (Student t-test, $p \leq 0.05$ )
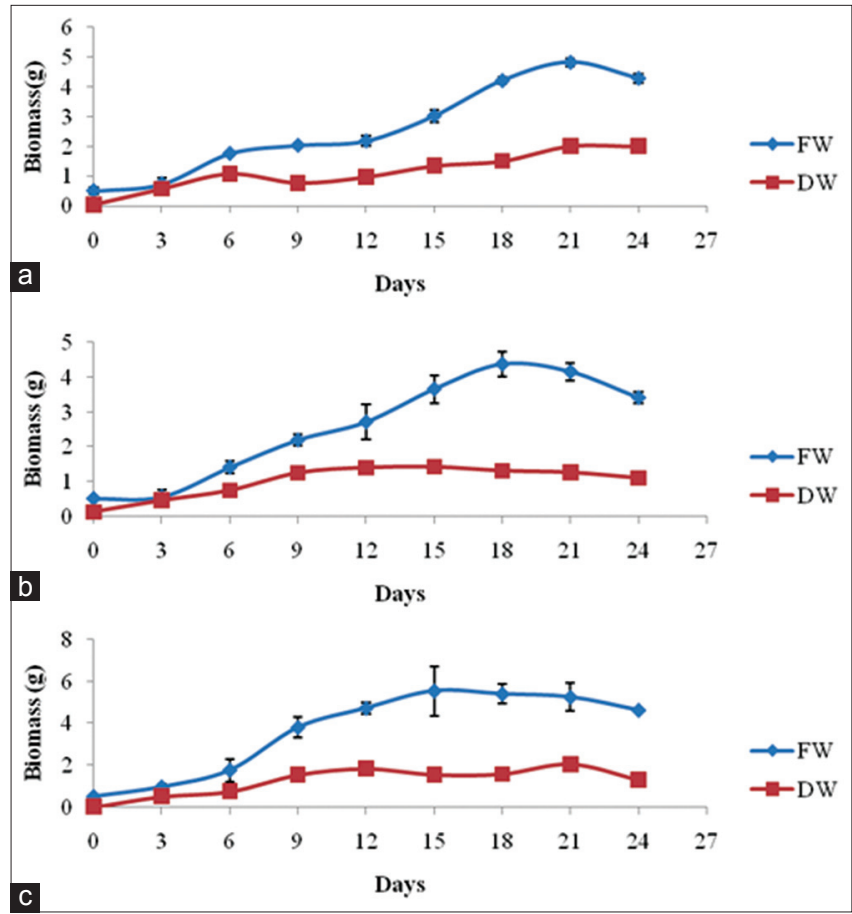

Fig 1. Growth pattern according to fresh cell weight (FW) and dried cell weight (DW) of the (a) slow, (b) intermediate, and (c) fast growing cell lines of Orthosiphon stamineus. 
supplemented with $30 \mathrm{~g} / \mathrm{L}$ sucrose (Fig. 2). This result was in contrast with previous studies on O. stamineus done by Lim et al. (2006), in which it was reported that medium with $45 \mathrm{~g} / 1$ sucrose led to both high amount of RA and fresh cell biomass production. Similarly the addition of $45 \mathrm{~g} / \mathrm{L}$ sucrose in the culture medium was found to be effective for cell biomass and pigment production of Melastoma malabathricum (Koey et al., 2010). However Akalezi et al. (1999) reported the highest cell biomass of Panax gensing was produced in culture medium with $30 \mathrm{~g} / \mathrm{L}$ sucrose. A study on Taxus chinensis cell cultures showed that the addition of only $20 \mathrm{~g} / \mathrm{L}$ sucrose could support the highest fresh cell biomass and taxane production (Wang et al., 1999). Ilieva and Pavolov (1997) reported the Lavandula vera cells produced not only more cell biomass but also higher RA content when cells cultured in culture medium supplemented with $45 \mathrm{~g} / \mathrm{L}$ sucrose. In Perilla frutescens, using lower sucrose concentrations led to pigment production in the cells, but the supplement of higher concentrations (60 and $50 \mathrm{~g} / \mathrm{L}$ sucrose) induced higher fresh cell biomass (Zhong and Yoshida, 1995).

The present study showed that the medium $\mathrm{pH}$ affected both cell biomass and rosmarinic acid production of the three cell lines of O. stamineus. In terms of biomass production, the slow growing cell line produced the highest fresh cell biomass when the medium $\mathrm{pH}$ was adjusted to $5.65,5.70,5.75$ or 5.80 . The most alkaline media $(\mathrm{pH} 6$ and 6.5) supported the lowest amount of fresh cell biomass production. This cell line also produced low cell biomass in very acidic medium $\mathrm{pH}$ (5). In terms of rosmarinic acid production, the slow growing cell line produced the highest amount of RA in medium $\mathrm{pH} 5.70$ (44.76 mg/g dried cell) and 5.75 (40.39 mg/g dried cell). The intermediate growing cell line produced high fresh cell biomass when the medium $\mathrm{pH}$ was adjusted to 5 and 5.65. This cell line also had the least biomass production in the most alkaline media (PH 6 and 6.5). In this cell line, medium pH $5.65(6.22 \mathrm{mg} / \mathrm{g}$ dried cell $)$ and $5.80(5.76 \mathrm{mg} / \mathrm{g}$ dried cell $)$ resulted in the highest RA production. RA was not detected in the most alkaline media ( $\mathrm{pH} 6,6.5)$ and also the most acidic medium $(\mathrm{pH} 5)$ resulted in trace amount of RA production. The fast growing cell line responded differently to medium $\mathrm{pH}$. The least fresh cell biomass production was observed in the most acidic medium ( $\mathrm{pH} 5$ and 5.5). High fresh cell biomass was produced in medium $\mathrm{pH}$ of $5.65,5.70$ also 6 and 6.5. Fast growing cell line was the only cell line that could produce high fresh cell mass at very alkaline medium $\mathrm{pH}$ (6 and 6.5). In terms of RA production in the fast growing cell line, medium pH $5.70(25.93 \mathrm{mg} / \mathrm{g}$ dried cell), 5.75 (18.55 mg/g dried cell) and $5.80(18.68 \mathrm{mg} / \mathrm{g}$ dried cell) resulted in significantly high RA production. In the most alkaline medium ( $\mathrm{pH}$ 6.5) RA was not produced, other medium $\mathrm{pH}$ levels also resulted in very little amount of RA production (Fig. 3).
The results of the present study on O. stamineus were in harmony with the study on Centella asiatica cells in which the optimal medium $\mathrm{pH}$ for both triterpens and cell biomass production was at the range of $5.5-5.6$ (Ling, 2004). In another study on Eurycoma longifolia callus cultures it was also reported that the highest amount of 9-methoxycanthin-6-one produced when the medium pH adjusted to 5.5 (Rosli et al., 2009). Luthfi (2004) also reported the highest alkaloids and cell biomass production of Eurycoma longifolia cell cultures achieved when cells

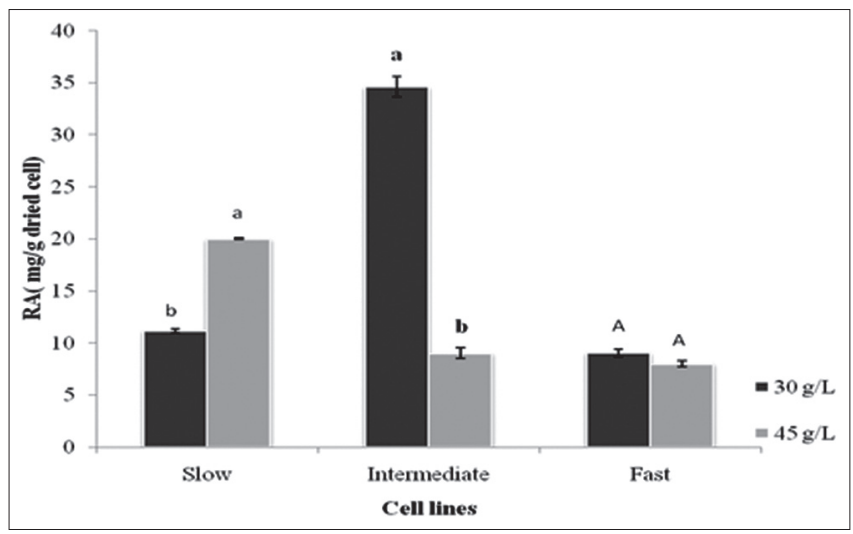

Fig 2. Effect of sucrose supplemented into the cell proliferation medium on RA production of the three cell lines of $O$. stamineus. Mean values followed by the same alphabets (in each cell line) were not significantly different (Student $\mathrm{t}$-test at $\mathrm{p} \leq 0.05$ ).

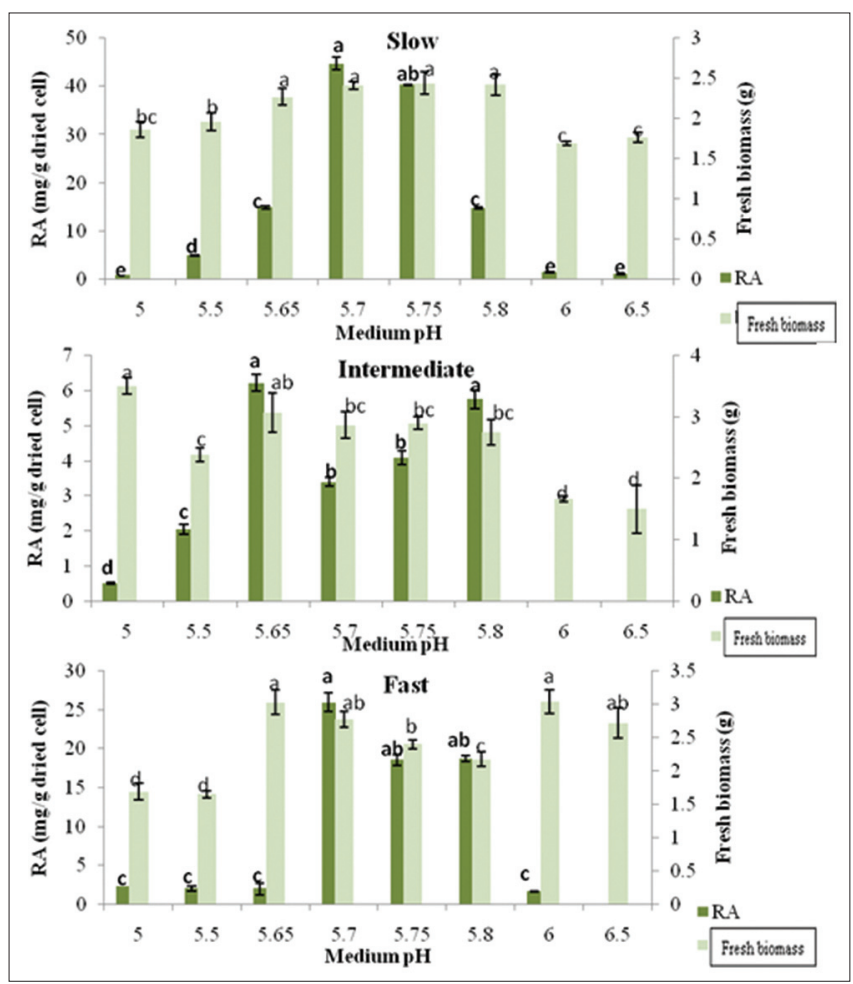

Fig 3. Effect of medium $\mathrm{pH}$ on rosmarinic acid and cell biomass production of the three cell lines of Orthosiphon stamineus. Means within each group (each line) having the same letter are not significantly different (Tukey test, $p \leq 0.05$ ). 
cultured in medium pH 5.75. Anthocyanin accumulations on Melastoma malabthricum affected by medium pH 5.25 and 6.25 , however it did not influence cell biomass production (Chan et al., 2010).

Photoperiod effected cell biomass and rosmarinic acid production of the three cell lines differently. The slow growing cell line was able to produce high cell biomass either under continuous illumination or total darkness, or when it was incubated under darkness for the $1^{\text {st }}$ half cycle followed by illumination for the $2^{\text {nd }}$ half cycle. The highest amount of RA was produced when this cell line was incubated under either darkness for the $1^{\text {st }}$ half cycle followed by illumination for the second half $(45.82 \mathrm{mg} / \mathrm{g}$ dried cell) or illumination for the $1^{\text {st }}$ half followed by darkness for the $2^{\text {nd }}$ half $(47.25 \mathrm{mg} / \mathrm{g}$ dried cell). The intermediate growing cell line produced the highest fresh cell biomass when incubated at either the first half cycle was illumination followed by darkness or the first half cycle was darkness followed by illumination (L/D or D/L). The amount of cells produced was not significantly different when cultured at continuous illumination or total darkness The intermediate growing cell line produced the highest amount of RA when incubated at either continuous illumination $(4.56 \mathrm{mg} / \mathrm{g}$ dried cell) or when the first half cycle was illumination followed by darkness in the second half $(4.52 \mathrm{mg} / \mathrm{g}$ dried cell) (Fig. 4). In the fast growing cell line, a complete cycle of total darkness caused the least fresh cell biomass production, whereas cells cultured in three other conditions (illumination, L/D and $\mathrm{D} / \mathrm{L}$ ) did not produce significantly different fresh cell biomass. In this cell line, the highest RA production was observed when either cell incubated at total darkness $(15.80 \mathrm{mg} / \mathrm{g}$ dried cell) or continuous illumination $(12.36 \mathrm{mg} / \mathrm{g}$ dried cell). In this cell line the lowest RA content was produced when cells incubated at illumination in the first half cycle followed by darkness in the second half cycle $(6.21 \mathrm{mg} / \mathrm{g}$ dried cell) (Fig. 4).

Production of some secondary metabolites like anthocyanin is highly dependent on illumination as Koay (2008) reported that in cell suspension cultures of Melastoma malabathricum although the cell growth was promoted in total darkness but anthocyanin production was highly decreased however under continuous illumination high anthocyanin was produced from the cell cultures. In Vitis vinifera cell cultures, 2.7 fold increased in anthocyanin production was reported when incubated at continuous illumination, this condition on the other hand showed negative results in terms of cell biomass production (Zhang et al., 2002). Jenkins et al (1995) described the importance of illumination as the photoreceptors that control the expression of specific genes involved in cell growth, development and secondary metabolite production.

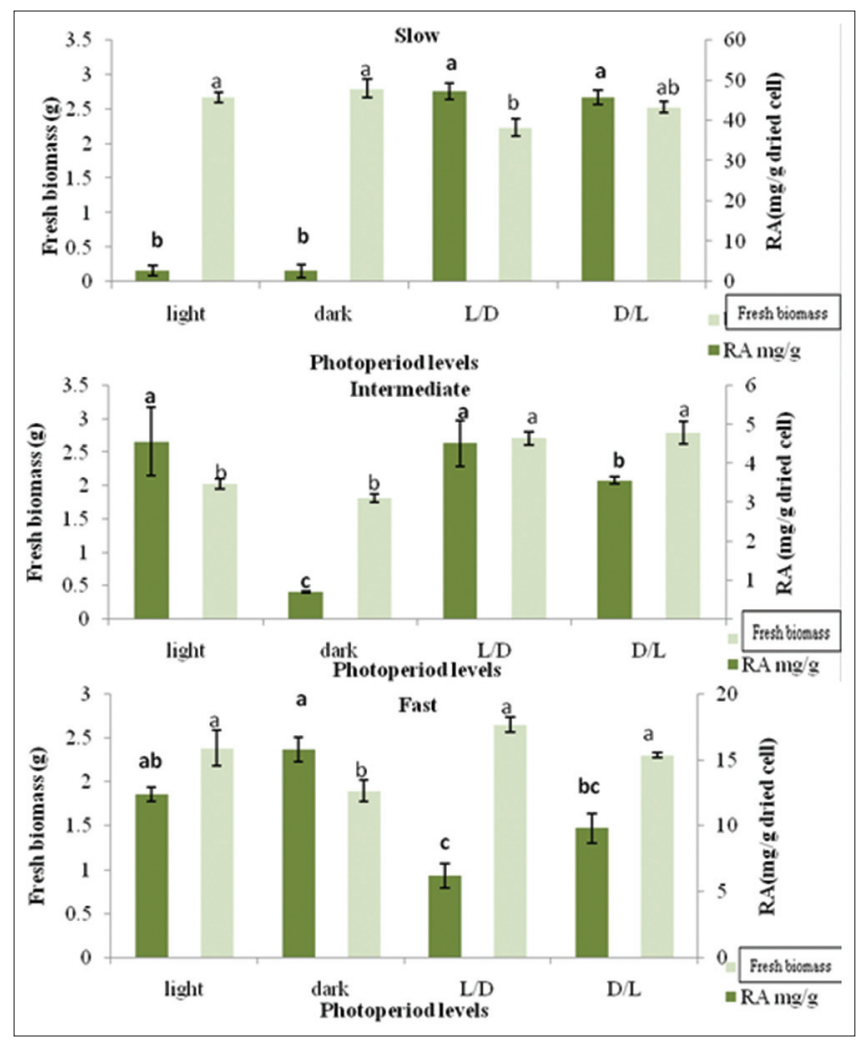

Fig 4. Effect of photoperiod on rosmarinic acid and cell biomass production of the three cell lines of $O$. stamineus ( $I=$ illumination, $\mathrm{D}=$ darkness, $\mathrm{l} / \mathrm{D}=$ illumination/darkness, $\mathrm{D} / \mathrm{L}=$ darkness/illumination). Means within each group (each line) having the same letter are not significantly different (Tukey test, $p \leq 0.05$ ).

Temperature affected fresh cell biomass and rosmarinic acid production of the three growing cell lines. The slow growing cell line produced the highest amount of fresh cell biomass when incubated at $26^{\circ} \mathrm{C}$. This cell line did not produce any significantly different amount of fresh cell biomass when incubated at 20,23 and $29^{\circ} \mathrm{C}$. In terms of rosmarinic acid production, slow growing line produced high amount of RA $(23.02 \mathrm{mg} / \mathrm{g}$ dried cell) when incubated at $29^{\circ} \mathrm{C}$, while incubation at other temperatures the amount of RA produced was not significantly different. The intermediate growing cell line produced more cell biomass when incubated at $20^{\circ} \mathrm{C}$. This cell line also did not produce significantly different cell biomass when incubated at other temperatures. The intermediate growing cell line produced the highest amount of RA $(15.88 \mathrm{mg} / \mathrm{g}$ dried cell) when incubated at $26^{\circ} \mathrm{C}$ followed with $29^{\circ} \mathrm{C}(7.54 \mathrm{mg} / \mathrm{g}$ dried cell). The fast growing cell line produced more cell biomass when incubated at $23^{\circ} \mathrm{C}$ or $29^{\circ} \mathrm{C}$. This cell line did not produce significantly different cell biomass when incubated at $20^{\circ} \mathrm{C}$ and $26^{\circ} \mathrm{C}$. Fast growing line produced high amount of RA $\left(19.65 \mathrm{mg} / \mathrm{g}\right.$ dried cell) when incubated at $20^{\circ} \mathrm{C}$. In this cell line an obvious declining trend in terms of RA production, was observed at higher temperatures (Fig. 5). These results indicated that different cell lines produced different amount of RA at different temperatures. 
Physiology and metabolism of cell cultures influenced by temperature effected cell growth and secondary metabolite production. Temperature in the range of $17-25^{\circ} \mathrm{C}$ known as the optimal temperature range for most callus and cell cultures. However, it could be different depending on the plant species (Rao and Ravishankar, 2002). The present study on $O$. stamineus cell lines, indicated that some stress factor like a different range of temperature was required for cell lines to trigger the enzymes needed for secondary metabolite production however only in the slow growing cell line at the normal temperature those enzymes were produced and subsequently the rosmarinic acid was produced. It was reported that in cell suspension cultures of Daucus carota, the highest fresh cell biomass and secondary metabolite was produced when maintained at $25^{\circ} \mathrm{C}$ (Narayan et al., 2005). In strawberry cell cultures, $15^{\circ} \mathrm{C}$ was the optimal temperature that increased anthocyanin production by 35 folds (Zhang et al., 1997).

\section{CONCLUSIONS}

The fresh cell biomass and rosmarinic acid production in cell suspension cultures of $O$. stamineuse was affected by different physical factors like medium $\mathrm{pH}$, photoperiod and carbohydrate source although in a diverse range

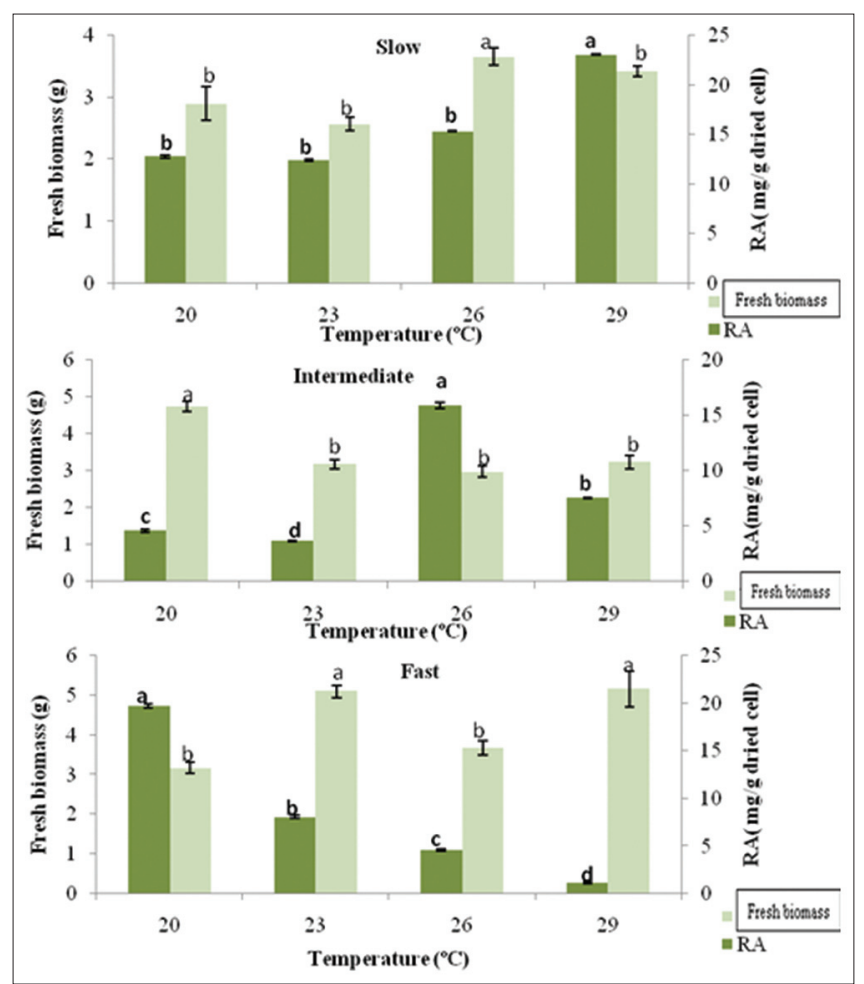

Fig 5. Effect of temperature on rosmarinic acid and biomass production of the slow, intermediate and fast growing cell lines of Orthosiphon stamineus. The mean values followed by the same alphabets for each parameter (biomass or RA) were not significantly different (Tukey test, $\mathrm{p} \leq 0.05)$. among the three different cell lines. The study on sucrose concentrations proved that medium supplemented with $3 \%$ sucrose was more suitable for cell biomass and RA production however adding more sucrose to the medium acted as an elicitor and improved the RA production in the slow growing line. Similar to most other cell lines, cells grown in medium with normal $\mathrm{pH}$ range (5.65-5.80) were more productive in terms of cell biomass and RA. In terms of photoperiod and temperature O. stamineuse the three cell lines showed inconsistency for cell biomass and RA production. Significant differences observed among the three selected cell lines indicated the importance of selection and categorization in the study of cell lines.

\section{ACKNOWLEDGEMENTS}

The author would like to thank the school of Biological Sciences, Universiti Sains Malaysia (USM) for the USM Fellowship Award and research facilities. Our special thanks to Dr Arvind Bhatt and Dr Ning Shu Ping for their critical comments and suggestions.

\section{Author contributions}

L. B. and L. K. C.: Conceived the idea, designed the experiments and contributed in writing. L. B., S. S., N. B. J., and L. K. C.: Wrote the manuscript, carry out statistical analysis and improvement of article.

\section{REFERENCES}

Akalezi, C. O., S. Li, Q. S. Li and J. J. Zhong. 1999. Combined effects of initial sucrose concentrations and inoculum size on cell growth and ginseng saponin production by suspension cultures of Panax ginseng. Process Biochem. 34: 639-642.

Akin-Idowu, P. E., D. O. Ibitoye and O. T. Ademoyegun. 2009. Tissue culture as a plant production tecshnique for horticultural crops. Afr. J. Biotechnol. 8(16): 3782-3788.

Akowuah, G. A., Z. Ismai, I. Norhayati and A. Sadikun. 2005. The effects of different extraction solvents of varying polarities on polyphenols of Orthosiphon stamineus and evaluation of the free radical-scavenging activity. Food Chem. 93(2): 311-317.

Bais, P. H., T. S. Walker, H. P. Swiezer and J. M. Vivanco. 2002. Root specific elicitation and antimicrobial activity of rosmarinic acid in hairy root cultures of Ocimum basilicum. Plant Physiol. Biochem. 40: 983-995.

Chan, L. K., Koay, S. S., Boey, P. L. and Bhatt, A. 2010. Effects of abiotic stress on biomass and anthocyanin production in cell cultures of Melastoma malabathricum. Biol. Res. 43: 127-135.

Chen, J. H. and C. T. Ho. 1997. Antioxidant activities of caffeic acid and its related hydroxycinnamic acid compounds. J. Agric. Food Chem. 45: 2374-2378.

Chin, J. H., H. H. Abas and I. Sabariah. 2008. Toxicity study of Orthosiphon stamineus Benth (Misai Kucing) on sprague dawley rats. Trop. Biomed. 25(1): 9-16.

Cuvelier, M. E., H. Richard and C. Berset. 1996. Anti-oxidative activity and phenolic composition of pilot plant and commercial extracts of sage and rosemary. J. Am. Oil Chem. Soc. 73: 645-652. 
Illieva, M. and Pavolov, A. 1999. Rosmarnic acid production by Lavandula vera MM cell suspension culture. Appl. Microbiol. Biotechnol. 47: 683-688.

Indubala, J. and L. T. Ng. 2000. Herbs: The Green Pharmacy of Malaysia, Vinpress Sdn Bhd, Kuala Lumpur, Malaysia.

Jaganath, I. B. and L. T. Ng. 2000. Herbs: The Green Pharmacy of Malaysia, Vinpress Sdn Bhd, Kuala Lumpur, Malaysia.

Jenkins, G. I., J. M. Christie, G. Fuglevance, J. C. Long and J. A. Jackson. 1995. Plant response to UV and blue light: Biochemical and genetic approaches. Plant Sci. 112: 117-138.

Koey, S. S., A. Bhatt and L. K. Chan. 2010. Effect of sucrose and Methyl jasmonate on biomass and anthocyanin production in cell suspension culture of Melastoma malabathricum (Malastomaceae). Int. J. Trop. Biol. Conserv. 59(2): 597-606.

Lee, W. L. and L. K. Chan. 2004. Establishment of Orthosiphon stamineus cell suspension culture for cell growth. Plant Cell, Tissue Organ Cult. 78: 101-106.

Lim, F. L., L. K. Chan and P. L. Boey. 2006. Selection of cell lines for the production of rosmarinic acid from cell suspension cultures of Orthosiphon stamineus Benth. In Vitro Cell Dev. Biol. Plant. 42: 538-542.

Ling, A. P. 2004. Triterpens production in Centella asiatica (L.) Urban (pegaga) callus and cell suspension cultures. Ph. D Thesis. Universiti Putra Malaysia (UPM).

Luthfi, A. M. S. 2004. Pengoptimuman Kultur ampaian sel Eurycoma longifolia Jack untuk penghasilan biojisim dan alkaloid. Ph. D. Thesis Universiti Sains Malaysia. Penang, Malaysia.

Mat-Salleh, A. and K. A. Latiff. 2002. Tumbuhan Ubatan Malaysia, University Kebangsaan Malaysia, Bangi, p. 524.

Murashige, T. and F. Skoog. 1962. Revised medium for rapid growth and bioassays with tobacco tissue culture. Physiol. Plant., 15: 473-497.

Narayan, M. S., R. Thimmaraju and N. Bhagyalakshimi. 2005. Interplay of growth regulators during solid-state and liquid-state batch cultivation of anthocyanin producing cell line of Daucus carota. Process Biochem. 40: 351-358.

Ohashi, K., T. Bohgaki and H. Shibuya. 2000. Antihypertensive substance in the leaves of lumis kucing (Orthosiphon aristatus) in Java Island. J. Pharm. Sci. 120: 474-482.

Olah, N. K., L. Radu, C. Mogoşan, D. Hanganu and S. Gocan. 2003. Phytochemical and pharmacological studies on Orthosiphon stamineus Benth. (Lamiaceae) hydroalcoholic extracts. J. Pharm. Biomed. Anal. (JPBA). 33(1): 117-123.

Petersen, M. 1994. Coleus spp.: In vitro culture and production of forskolin and rosmarinic acid. In: Bajaj, Y. P. (Ed.), Biotechnology in Agriculture and Forestry, Vol. 26. Springer, Berlin, Pp. 69-92.

Rao, R. and G. A. Ravishankar. 2002. Plant cell cultures: Chemical factories of secondary metabolites. Biotechnol. Adv. 20: 101-153.

Rosli. N., M. Maziah, L. K. Chan and S. Sreeramanan. 2009. Factors affecting the accumulation of 9-methoxycanthin-6-one in callus cultures of Eurycoma longifolia. J. For. Res. 20(1): 54-58.

Sumaryono, W., P. Proksch, T. Hartman, M. Nimtz and V. Wray. 1991. Induction of rosmarinic acid accumulation in cell suspension culture of Orthosiphon aristatus after treatment with yeast extract. Phytochemistry. 30(10): 3267-3271.

Takeda, H. M., J. Tsuji, J. Miyamoto and T. Matsumiya. 2002. Rosmarinic acid and caffeic acid reduce the defensive freezing behaviour of mice exposed to conditioned fear stress. Psychopharmacology. 164: 233-235.

Wang, H. Q., J. T. Yu and J. J. Zhong, 1999. Significant improvement of taxane production in suspension cultures of Taxus chinensis by sucrose feeding strategy. Process Biochem. 5: 479-483.

Wiart, C. 2002. Orthosiphon stamineus Benth. In: Wong, F. K. (Ed.), Medicinal Plants of South East Asia, Prentice Hall, Malaysia.

Zhang, W., M. Seki and S. Furusaki. 1997. Effect of temperature and its shift on growth and anthocyanin production in suspension cultures of strawberry cells. Plant Sci. 127: 207-214.

Zhang, W., C. Curtin, M. Kikuchi and C. Franco. 2002. Integration of jasmonic acid and light irradiation for enhancement of anthocyanin biosynthesis in Vitis vinifera suspension cultures. Plant Sci. 162: 459-468.

Zhong, J. J. and T. Yoshida. 1995. High density cultivation of Perila frutescens cell suspensions for anthocyanin production: Effects of sucrose concentrations and inoculum size. Enzyme Microb. Technol. 17: 1073-1079. 